\title{
Change of prostaglandin E level in joint fluids after treatment with flurbiprofen in patients with rheumatoid arthritis and osteoarthritis
}

\author{
M. TOKUNAGA, ${ }^{1} \mathrm{~K}$. OHUCHI, ${ }^{2}$ S. YOSHIZAWA, ${ }^{2}$ S. TSURUFUJI, \\ A. RIKIMARU, ${ }^{3}$ AND E. WAKAMATSU ${ }^{4}$
}

From the ${ }^{1}$ Department of Orthopaedic Surgery, Tohoku Teishin Hospital, the ${ }^{2}$ Department of Biochemistry, Faculty of Pharmaceutical Sciences, Tohoku University, the ${ }^{3}$ Department of Orthopaedic Surgery, Narugo National Hospital, and the 4 Department of Orthopedic Surgery, Tohoku University, School of Medicine, Japan

SUMmaRY The prostaglandin E (PGE) level in the knee joint fluid was determined by radioimmunoassay before and after anti-inflammatory therapy with flurbiprofen in 8 patients with rheumatoid arthritis (RA) and 4 patients with osteoarthritis (OA). The level of PGE in RA joint fluids before the anti-inflammatory treatment was $9 \cdot 5-1 \cdot 2 \mathrm{ng} / \mathrm{ml}$ and in proportion with the leucocyte count in the joint fluid. A marked decrease of the PGE level was attained with flurbiprofen treatment in 4 patients whose initial PGE levels had been higher than $3 \cdot 2 \mathrm{ng} / \mathrm{ml}$, while 4 patients with lower PGE levels, namely, $1 \cdot 4-1 \cdot 2 \mathrm{ng} / \mathrm{ml}$, did not respond to the drug treatment. In all the OA patients the PGE level was no higher than $1.5 \mathrm{ng} / \mathrm{ml}$ and refractory to the anti-inflammatory therapy.

That prostaglandin E (PGE) plays some part in rheumatoid arthritis (RA) has been suggested by several lines of observations. E type prostaglandin appears to stimulate bone resorption in RA joints. ${ }^{1}$ The localisation and production of PGE in rheumatoid synovial tissues have been demonstrated by an immunohistochemical method ${ }^{2}$ and radioimmunoassay. ${ }^{3}$

PGE has been detected in the joint fluids from RA patients, and the PG level in patients treated with nonsteroidal anti-inflammatory agents is lower than in untreated persons. ${ }^{3-6}$ However, these reports do not compare PGE levels in the same patients before and after treatment, except in one case described by Higgs et al. ${ }^{4}$ Moreover, none of these reports deals with the correlation between drug-induced change of PGE level and extent of inflammatory response in the joint tissues.

The present study was undertaken in an attempt to study the changes of fluid volume, cell contents, and PGE level in the joint fluids from the same patients with RA and osteoarthritis (OA) after treatment

Accepted for publication 6 February 1981 .

Correspondence to $\mathrm{Dr} M$. Tokunaga, Department of Orthopaedic Surgery, Tohoku Teishin Hospital, 2-29-1 Yamatomachi, Sendai 983, Japan. with flurbiprofen, which is a potent inhibitor of the prostaglandin-generating system. ${ }^{7}$

\section{Materials and methods}

JOINT FLUIDS

Joint fluid samples from 8 cases with RA and 4 cases with $\mathrm{OA}$ of the knee joint were examined (Table 1). Of $8 \mathrm{RA}$ patients 7 had classical or definite RA according to the criteria of the American Rheumatism Association, ${ }^{8}$ and 1 had palindromic rheumatism. ${ }^{9}$ Firstly, joint fluid was obtained from the knee joint of the patients who had not received steroid or nonsteroidal anti-inflammatory drugs for at least 1 week (I in Table 1). Then, secondly, it was obtained from the same knee joint 1 day after the cessation of anti-inflammatory therapy with flurbiprofen, $240 \mathrm{mg} /$ day for RA and $120 \mathrm{mg}$ /day for OA, for 6 consecutive days (II in Table 1). After the joint fluid had been aspirated, indomethacin was immediately added to it, $10 \mu \mathrm{g}$ of $0.1 \%$ indomethacin solution to $1 \mathrm{ml}$ of the joint fluid, and stored at $-20^{\circ} \mathrm{C}$ until use.

CELL COUNTS ON JOINT FLUIDS

Cell counts on the joint fluids from RA patients were 
Table 1 Clinical data and levels of prostaglandin $E$ of $R A$ and $O A$ patients

\begin{tabular}{|c|c|c|c|c|c|c|c|c|c|c|c|c|c|c|c|}
\hline \multirow{2}{*}{\multicolumn{2}{|c|}{ Case }} & \multirow[t]{2}{*}{ Age } & \multirow[t]{2}{*}{ Sex } & \multirow{2}{*}{$\begin{array}{l}\text { Criteria } \\
(\text { in } R A)\end{array}$} & \multirow{2}{*}{$\begin{array}{r}\text { Stage } \\
(i\end{array}$} & \multirow{2}{*}{$\begin{array}{l}\text { Class } \\
R A)\end{array}$} & \multirow{2}{*}{$\begin{array}{l}E S R \\
(\mathrm{~mm} / \mathrm{h})\end{array}$} & \multirow[t]{2}{*}{$R A$ test } & \multirow[t]{2}{*}{$C R P$} & \multicolumn{3}{|c|}{ Joint fluid (I) } & \multicolumn{3}{|c|}{ Joint fluid (II) } \\
\hline & & & & & & & & & & $\begin{array}{l}P G E \\
(n g / m l)\end{array}$ & $\begin{array}{l}\text { Volume } \\
(m l)\end{array}$ & $\begin{array}{l}\text { Leucocyte } \\
\left(\text { cells } / \mathrm{mm}^{3}\right)\end{array}$ & $\begin{array}{l}P G E \\
(n g / m l)\end{array}$ & $\begin{array}{l}\text { Volume } \\
(\mathrm{ml})\end{array}$ & $\begin{array}{l}\text { Leucocyte } \\
\left(\text { cells } / \mathrm{mm}^{3}\right)\end{array}$ \\
\hline RA & $\begin{array}{l}1 \\
2 \\
3 \\
4 \\
5 \\
6 \\
7 \\
8\end{array}$ & $\begin{array}{l}28 \\
66 \\
50 \\
50 \\
47 \\
70 \\
65 \\
39\end{array}$ & $\begin{array}{l}\mathbf{F} \\
\mathbf{F} \\
\mathbf{F} \\
\mathbf{M} \\
\mathbf{F} \\
\mathbf{F} \\
\mathbf{F} \\
\mathbf{F}\end{array}$ & $\begin{array}{l}\text { Classical } \\
\text { Classical } \\
\text { Classical } \\
\text { Palindromic } \\
\text { Classical } \\
\text { Classical } \\
\text { Classical } \\
\text { Definite }\end{array}$ & $\begin{array}{r}\text { III } \\
\text { III } \\
\text { III } \\
\text { I } \\
\text { IV } \\
\text { II } \\
\text { III } \\
\text { III }\end{array}$ & $\begin{array}{l}2 \\
3 \\
3 \\
2 \\
4 \\
2 \\
3 \\
2\end{array}$ & $\begin{array}{r}126 \\
151 \\
80 \\
85 \\
106 \\
125 \\
30 \\
52\end{array}$ & $\begin{array}{l}+ \\
+ \\
+ \\
- \\
+ \\
+ \\
+ \\
-\end{array}$ & $\begin{array}{l}7+ \\
2+ \\
2+ \\
6+ \\
5+ \\
2+ \\
3+ \\
2+\end{array}$ & $\begin{array}{l}9 \cdot 5 \\
6 \cdot 1 \\
5 \cdot 1 \\
3 \cdot 2 \\
1 \cdot 4 \\
1 \cdot 4 \\
1 \cdot 2 \\
1 \cdot 2\end{array}$ & $\begin{array}{r}20 \\
2 \\
6 \\
11 \\
15 \\
3 \\
3 \\
10\end{array}$ & $\begin{array}{c}39200 \\
24000 \\
18100 \\
9500 \\
7000 \\
4400 \\
4500 \\
5200\end{array}$ & $\begin{array}{l}2 \cdot 7 \\
2 \cdot 5 \\
2 \cdot 9 \\
2 \cdot 0 \\
1 \cdot 3 \\
1 \cdot 1 \\
1 \cdot 2 \\
1 \cdot 2\end{array}$ & $\begin{array}{r}20 \\
1 \\
6 \\
9 \\
15 \\
6 \\
3 \\
5\end{array}$ & $\begin{array}{c}46000 \\
23000 \\
13100 \\
9500 \\
10200 \\
18000 \\
2500 \\
5100\end{array}$ \\
\hline OA & $\begin{array}{l}1 \\
2 \\
3 \\
4\end{array}$ & $\begin{array}{l}52 \\
70 \\
73 \\
47\end{array}$ & $\begin{array}{l}\mathbf{M} \\
\mathbf{F} \\
\mathbf{F} \\
\mathbf{F}\end{array}$ & z & $\begin{array}{l}- \\
- \\
-\end{array}$ & $\begin{array}{c}- \\
-\end{array}$ & $\begin{array}{r}6 \\
11 \\
15 \\
12\end{array}$ & $\frac{-}{-}$ & - & $\begin{array}{l}1 \cdot 5 \\
1 \cdot 5 \\
1 \cdot 1 \\
1.0\end{array}$ & $\begin{array}{l}22 \\
10 \\
15 \\
15\end{array}$ & $\begin{array}{l}- \\
- \\
300\end{array}$ & $\begin{array}{l}1.4 \\
1.3 \\
1.4 \\
1.0\end{array}$ & $\begin{array}{r}35 \\
15 \\
30 \\
5\end{array}$ & $\begin{array}{l}- \\
- \\
300\end{array}$ \\
\hline
\end{tabular}

SI conversion: leucocytes $/ \mathrm{mm}^{3} \times 10^{6}=$ leucocytes $/ 1$.

performed on a haemocytometer after suitable dilution of the fluid with the standard Türk solution.

\section{SEPARATION OF PROSTAGLANDINS}

The extraction of prostaglandins from the joint fluid and the separation of prostaglandin $E$ were carried out according to the procedure of Jaffe et al. ${ }^{10}$ with slight modifications. ${ }^{11}$

\section{RADIOIMMUNOASSAY OF PROSTAGLANDIN E}

The radioimmunoassay was carried out according to the procedure of Ohuchi et al., ${ }^{11}$ which was a modification of the methods of Levine et al. ${ }^{12}$ and Jaffe et al. ${ }^{10}$ The prostaglandin E fraction obtained by silicic acid minichromatographic separation was completely converted to prostaglandin B by alkaline dehydration, and prostaglandin $\mathbf{B}_{1}$-antiserum (Clinical Assays Inc., Cambridge, MA, USA) was used for the quantitative measurement of prostaglandin $B$.

The cross-reactivity of the prostaglandin $B_{1^{-}}$ antiserum to other prostaglandins, as measured by the amounts that provided $50 \%$ inhibition of binding, was as follows: prostaglandin $B_{2}$ and prostaglandin $A_{1}, 4: 1$; prostaglandin $A_{2}, 20: 1$; prostaglandin $E_{1}, 70: 1$; prostaglandin $E_{2}, 450: 1$; prostaglandin $F_{1} \alpha$ and prostaglandin $F_{2} \alpha>10000$ : $1 .{ }^{11}$ As this prostaglandin $B_{1}$-antiserum crossreacted considerably with prostaglandin $\mathbf{B}_{2}$, the values measured for prostaglandin $E_{1}$ in the presence of prostaglandin $E_{2}$ cannot reflect the real value of prostaglandin $E_{1}$. So we expressed the amount of prostaglandin $\mathrm{E}$ instead of the amount of prostaglandin $\mathrm{E}_{\mathbf{1}}$.

In parallel with the sample assay the recovery rate of the added $\left({ }^{3} \mathrm{H}\right)$ prostaglandin $\mathrm{E}_{1}\left(5 \times 10^{-3} \mu \mathrm{Ci}\right.$, $5,6-{ }^{6} \mathrm{H}^{\prime}$ prostaglandin $\mathrm{E}_{1}, 59 \mathrm{Ci} / \mathrm{mmol}$, the Radiochemical Centre, England) in the joint fluid was examined and used for the correction of raw data to actual prostaglandin concentration in the joint fluid.

\section{OTHER MEASUREMENTS ON RA PATIENTS}

The erythrocyte sedimentation rate (ESR), rheumatoid factor (RA test), and C-reactive protein (CRP) were measured as routine laboratory tests for RA patients.

\section{Results}

PGE levels, fluid volumes, and leucocyte counts in the joint fluids from $R A$ and $O A$ patients are tabulated in Table 1 together with the ESR, results of the RA test, and serum CRP values. The PGE levels before the drug treatment of RA patients varied over a comparatively wide range from $9 \cdot 5$ to

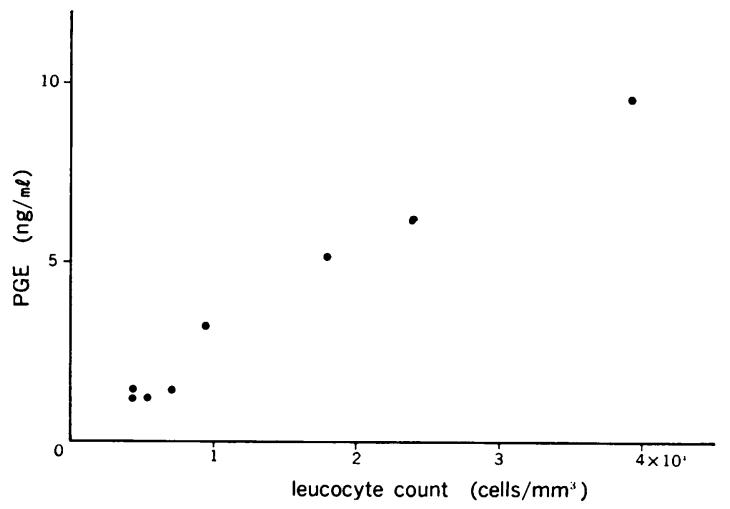

Fig. 1 Relation between prostaglandin $E$ (PGE) and leucocyte count in the joint fluids of $R A$ patients before and after the anti-inflammatory therapy with flurbiprofen. The levels of PGE $(\mathrm{ng} / \mathrm{ml})$ were plotted against leucocyte count (cells $\left./ \mathrm{mm}^{3}\right)$. 


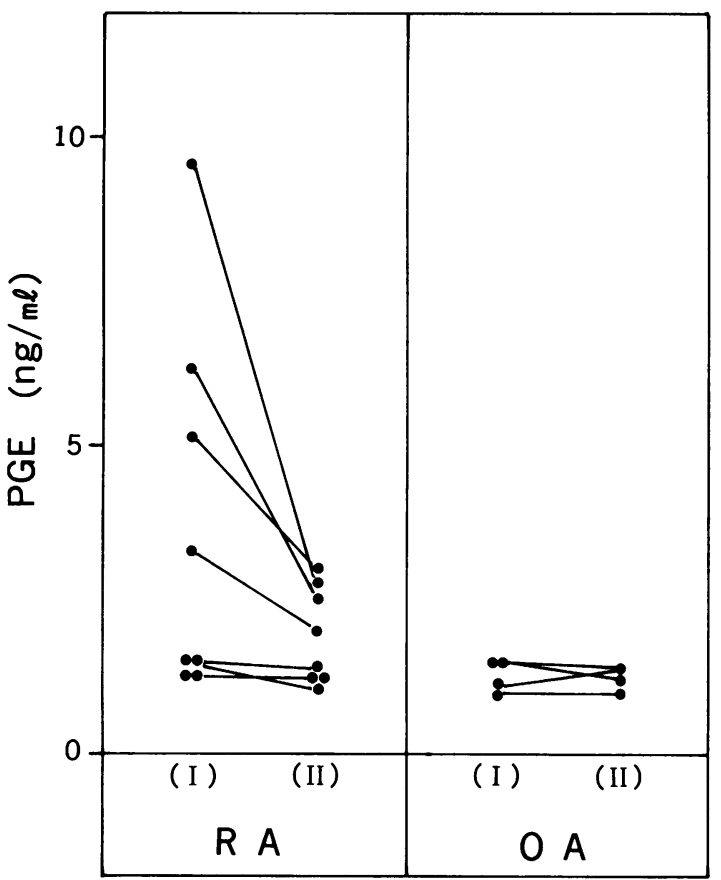

Fig. 2 Changes in the levels of prostaglandin $E(P G E)$ in the joint fluids of $R A$ and $O A$ patients before and after the anti-inflammatory therapy with flurbiprofen. $(I)$ and $(I I)=$ joint fluid (I) and (II) obtained before and after the antiinflammatory therapy, respectively.

$1 \cdot 2 \mathrm{ng} / \mathrm{ml}$, while the levels of OA patients fell into a comparatively low and narrow range from 1.5 to $1 \cdot 0 \mathrm{ng} / \mathrm{ml}$.

During the anti-inflammatory therapy with flurbiprofen the PGE levels in RA patients with the initial PGE values higher than $3 \cdot 2 \mathrm{ng} / \mathrm{ml}$ declined by $72-38 \%$, while the remaining 4 cases with the initial PGE levels not higher than $1.4 \mathrm{ng} / \mathrm{ml} \mathrm{kept}$ their initial levels in spite of the drug treatment (Fig. 1).

The PGE in OA patients, whose PGE levels in the joint fluids were also at a low level, namely $1 \cdot 5-1 \cdot 0$ $\mathrm{ng} / \mathrm{ml}$, did not respond to the therapy at all.

No significant change was observed in respect of the cell counts or volume of the joint fluid after the therapy with flurbiprofen either in RA or in OA.

\section{Discussion}

Inflammation of articular tissue in OA appears to be due mainly to mechanical injury of the tissues caused by deformation of the joint structures, namely, bone, cartilage, and ligaments. On the other hand immune complexes are thought to play an important role in the pathogenesis of rheumatoid synovitis.

Effusion of joint fluids in these joint diseases is thought to be derived from inflammatory lesions of articular tissues. However, the exact mechanisms mediating vascular permeability in these diseases are not well understood yet. In a variety of clinical and experimental inflammations $\mathrm{E}$ type prostaglandin generated in injured tissues is considered to be of importance in the mediation of hyperalgesia, vasodilatation, increased vascular permeability, and fever. ${ }^{13}$ In the present study, however, no apparent correlation was observed in RA between PGE levels in the joint fluid and various parameters generally accepted as indicators of severity of RA inflammation such as the ESR, serum CRP, and volume of the joint fluids aspirated from affected knee joints, apart from cell counts (Table 1, Fig. 1).

Data on PGB levels and leucocyte counts in joint fluids of rheumatic diseases presented by Robinson and Levine ${ }^{14}$ also include findings suggesting that there is no correlation between these 2 parameters. The inflammatory group designated by them on the basis of cell counts $1000 / \mathrm{mm}^{3}$ or more in the joint fluids showed extensive variation in PGB levels ino the joint fluids, with very low values that could not be distinguished from those of the noninflammatory $\left(<1000\right.$ cells $\left./ \mathrm{mm}^{3}\right)$ group.

In addition, our data on the influence of flurbiprofen to the joint fluids also appear to be inconsistent with the general concept of the role of PGE in inflammation. When the drug was administrated to RA patients with a high level of PGE in joint fluids (patients $1,2,3$, and 4), the PGE levels decreased markedly without affecting either effusion of joint fluids or emigration of cells into the fluids (Table 1). Moreover in half (4) the RA cases and all the 4 OA cases effusion of joint fluids took place in spite of a comparatively low level in PGE in the fluid, but in addition the PGE level and effusion of joint fluid were refractory to anti-inflammatory therapy with flurbiprofen.

Trang et al. ${ }^{6}$ report, though without including precise data, that all patients treated with various non-steroidal anti-inflammatory drugs still developed acute exudative arthritis in spite of treatment which led to much lower levels of PG's in joint fluid than in untreated patients. The present study, based on the observations made on same patients before and after anti-inflammatory treatment, has provided new evidence in favour of such concepts.

Recent novel studies by Samuelsson ${ }^{15}$ have shown that the leucotriens are produced from arachnoidic acid by leucocytes through the lipoxygenase pathway. Leucotrien B has an extremely potent chemotactic 
activity. ${ }^{16}$ The lipoxygenase pathway is not affected by aspirin-like drugs such as flurbiprofen. The ineffectiveness of our therapy with flurbiprofen on cell counts may therefore be explained along these lines.

Ferreira ${ }^{13}$ reported that prostaglandins do not cause overt pain but hyperalgesia; thus, they can sensitise pain receptors. Our clinical impression is that the arthralgia of RA is suppressed in varying degrees after anti-inflammatory therapy with nonsteroidal drugs. The significance of PG synthesis inhibitors in anti-inflammatory therapy might be evaluated on the basis of their analgesic effect.

We thank Drs S. Ogawa, N. Ohira, A. Yoshizumi, and K. Sato for their considerable help with the collection of the samples.

\section{References}

1 Robinson D R, Tashjian Jr A H, Levine L. Prostaglandinstimulated bone resorption by rheumatoid synovia. A possible mechanism for bone destruction in rheumatoid arthritis. $J$ Clin Invest 1975; 56: 1181-8.

2 Husby G, Bankhurst A D, Williams Jr R C. Immunohistochemical localization of prostaglandin $E$ in rheumatoid synovial tissues. Arthritis Rheum 1977; 20: 785-91.

3 Sturge R A, Yates D B, Gordon D, et al. Prostaglandin production in arthritis. Ann Rheum Dis 1978; 37: 315-20.

4 Higgs G A, Vane J R, Hart F D, Wojtulewski J A. Effect of anti-inflammatory drugs on prostaglandins in rheumatoid arthritis. In: Robinson $\mathbf{H} J$, Vane $J \mathbf{R}$, eds. Prostaglandin Synthetase Inhibitors New York: Raven Press, 1974: 165-73.

5 Robinson H J, Granda J L. Prostaglandins in synovial inflammatory disease. Surg Forum 1974; 25: 426-77.
6 Trang L E, Granström E, Lövgren $O$. Levels of prostaglandin $F_{2 \alpha}$ and $E_{2}$ and thromboxane $B_{2}$ in joint fluid in rheumatoid arthritis. Scand J Rheumatol 1977; 6: 151-4.

7 Crook D, Collins A J, Rose A J. A comparison of the effect of flurbiprofen on prostaglandin synthetase from human rheumatoid synovium and enzymatically active animal tissues. J Pharm Pharmacol 1976; 28 : 535.

8 American Rheumatism Association. Diagnostic criteria for rheumatoid arthritis. 1958 revision. Ann Rheum Dis 1959; 18: 49-53.

9 Hench P S, Rosenberg E F. Palindromic rheumatism. A 'new' oft recurring disease of joints (arthritis, periarthritis, para-arthritis) apparently producing no articular residues. Report of thirty-four cases; its relation to angio-neural arthrosis, 'allergic rheumatism' and rheumatoid arthritis. Arch Intern Med 1944; 73: 293-321.

10 Jaffe B M, Behman H R, Parker C W. Radioimmunoassay measurement of prostaglandin $E, A$, and $F$ in human plasma. J Clin Invest 1973; 52: 398-405.

11 Ohuchi K, Sato H, Tsurufuji S. The content of prostaglandin $E$ and prostaglandin $F_{2}$ in the exudate of carageenin granuloma of rats. Biochim Biophys Acta 1976 ; 424 : 439-48.

12 Levine L, Gutierrez Cernosek R M, Van Vunakis $H$. Specificities of prostaglandin $B_{1}, F_{1 \alpha}$, and $F_{2 \alpha}$ antigenantibody reactions. $J$ Biol Chem $1971 ; 246$ : 6782-5.

13 Ferreira S H. Prostaglandins. In: Glynn L E, Houck J C, Weissmann G, eds. Handbook of Inflammation 1. Chemical messengers of the inflammatory process. New York: Elsevier, 1979: 113-51.

14 Robinson D R, Levine L. Prostaglandin concentrations in synovial fluid in rheumatic diseases: Action of indomethacin and aspirin. In: Robinson $\mathbf{H} \mathbf{J}$, Vane $\mathrm{J} \mathbf{R}$, eds. Prostaglandin Synthetase Inhibitors. New York: Raven Press, 1974: 223-8.

15 Samuelsson B. The leukotriens: a new group of biologically active compounds including SRS-A. Trends Pharmacol Sci 1980; 1: 227-30.

16 Palmer R M J, Stepney R J, Higgs G A, Eakins K E. Chemokinetic activity of arachidonic acid lipoxygenase products on leucocytes of different species. Prostaglandins 1980; 20 : 411-8. 